\title{
Brand Europe: \\ European Integration and Tourism Development
}

It's time for the European Union to develop "Brand Europe," before the continent's world-tourism market share erodes further.

\section{BY PETER ÅKERHIELM, CHEKITAN S. DEV, AND MALCOLM A. NODEN}

$A$ lot of water has flowed under the Pont Neuf since we first exhorted European trade-policy makers not to ignore the tourism opportunity afforded by European integration. Since then, tourism flows to Europe have continued to grow despire political and economic upheaval. Our research on this subject indicates that, while some organizational progress has been made by the European Union (EU) on this subject, much remains to be done if there is to be an integrated community-wide policy on tourism. Reflecting on our original 1990 paper, we offer this commentary on the state of European tourism. ${ }^{1}$

\footnotetext{
${ }^{1}$ Peter Åkerhielm, Chekitan Dev, and Malcolm Noden, "Europe 1992: Neglecting the Tourism Opportunity," Cornell Hotel and Restaurant Administration Quarterly, Vol. 31, No. 1 (May 1990), which article is reprinted in this issue of Cornell Quarterly (see pages 81-87).
}

\section{What We Said in 1990}

Our original contention in the 1990 article was that the European Community (the predecessor to the EU) had no clear, integrated, system-wide policy addressing the needs of the tourism industry. We also noted that little if any serious attention was being paid to the promotion of tourism, while at the same time substantial structural barriers to change existed.

Problems of value-added tax (VAT) harmonization characterized the EC's major fiscal efforts at the time, and considerable controversy remains over how VAT harmonization should be applied in each nation to specific products and services, including jet fuel. ${ }^{2}$

${ }^{2}$ Commission of the European Communities Report, COM 171. Final, 2001, pp. 15, 3.3.2.
(C) 2003. CORNELL UNIVERSITY 
The mantra of all governmental interest in tourism is expressed by the classic trio of benefits to be secured as the result of strong tourism demand: namely, employment, tax revenues, and economic multipliers. In addition, some governments, including the EU's own governing institutions, have concluded that they must also take measures to ensure the long-term sustainability of the environment, both natural and built, to avoid killing the goose that lays the golden egg.

Additionally, several European governments have long histories of intervention in tourism through an approach called "social tourism." The term is a thinly veiled synonym for the social experiment of granting governmental subsidies in favor of those who might not otherwise be able to enjoy the fruits of travel to other places. This form of socioeconomic intervention, pervasive in contemporary European circles, is rooted in communal sensibilities. To suggest that some form of socialism is common in Europe is, of course, to state the obvious. Unfortunately, such "socialist" tendencies have influenced the development and adoption of common monetary, fiscal, and structural policies, resulting in an approach that, at least in some measure, appears antithetical to the interests of free-market principles. These latter are the principles that undergird the basic structure of the $\mathrm{EC}$, whose founding documents, based on the 1957 Treaty of Rome, first enunciated and embraced the idea of a common, borderless, continent-wide free market for labor, capital, and currency.

\section{What Has Happened Since 1990}

The EC became the EU in 1992 and has since grown from 12 to 15 member states (Austria, Finland, and Sweden joined in 1995). Ten more nations have been accepted for membership in 2004, and another three have applied (see Exhibit 1). EU citizens can now travel, study, and work freely in any of the 15 member states. The Euro is used in 12 member states. At the moment, one needs local currency when traveling to the United Kingdom, Sweden, and Denmark-a circumstance that is unlikely to change over the next five to ten years. It appears, however, that the new entrants will introduce the Euro as soon as they are permitted to do so.

\section{EXHIBIT 1}

\section{European Union membership}

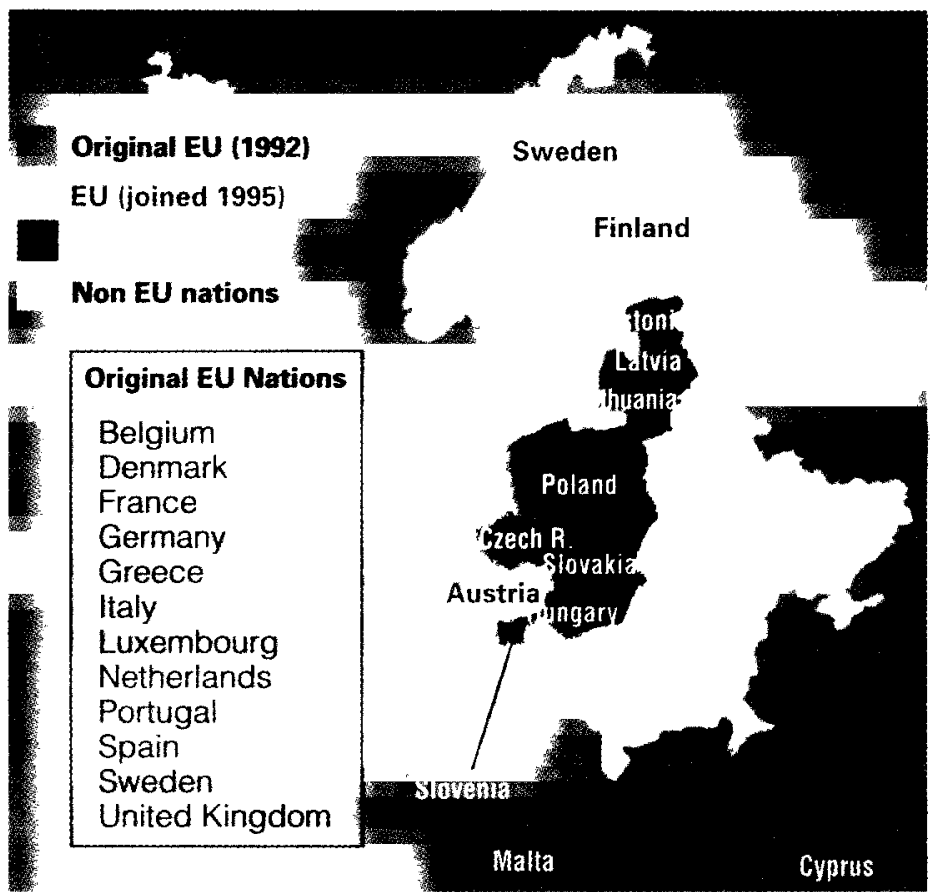

Source: The Wall Street Journal, September 22, 2003, p. A16.

\section{Tourism's Role in the European Economy}

Europe still has the world's largest tourist trade, growing in number of arrivals and tourism receipts. Tempering that good news, however, is the fact that Europe's market share in the evergrowing world tourism trade (now the largest international trade category at US\$555 billion) continues to decrease-from 72 percent in 1960 to 62 percent in 1989 to 58 percent in 2000, measured in arrivals. ${ }^{3}$ Despite this loss in market share, tourism continues to be a major economic force in the $\mathrm{EU}$, as described in this comment (on the next page) from a 2002 report by David Jeffries:

${ }^{3}$ Source: World Tourism Organization (http://www.worldtourism.org/market_research/facts\&figures/menu.htm). 
In 2000 five EU countries were among the ten leading tourist destinations in the world, and in 1999 the EU accounted for 43 percent of arrivals and 40 percent of receipts in non-domestic world tourism. Through the eight million people directly employed in the EU tourism sector, tourism's direct contribution in terms of jobs is particularly important in some tourism-intensive economies. It also has a substantial indirect effect on employment in related services. Together with employment and GDP indicated in other sectors, such as transport or distributive trade, these figures rise up to 20 million jobs and to roughly 12 percent of GDP. Tourism is seen as a major opportunity for job creation over the coming years, in particular in less developed and peripheral regions. Some sources estimate that travel and tourism jobs will increase by two million during the next ten years. ${ }^{4}$

\section{The EU's Effects on Tourism}

The biggest and most visible practical change for visitors to Europe since the formation of the EU is the growing use of the Euro. Although some claim that the transition to the common currency triggered price increases, the fact remains that travelers can now go to 12 European countries without worrying about exchange rates.

Another direct effect of the EU is the emergence and rapid expansion of low-cost airlines like Ryan Air, EasyJet, and Sterling. This phenomenon is no doubt a market response to developments in a struggling global industry that was at one time showing a net loss in international service of approximately US\$3 billion (thousand million). Many of the national flag carriers in Europe, such as Austrian Airlines, have had to follow global trends by cutting costs and fending off or coping with labor strikes. These difficulties have been compounded by the effects of the 9/11 terrorist attacks, the Iraq war, and

${ }^{4}$ See: www.europa.eu.int; and David Jeffries, "European Union and Tourism: In Search of a Policy-Europé," Mintel Report, Mintel International Group Limited, June 2002, p. 6. last winter's SARS plague. Swissair did not survive these dire conditions and declared bankruptcy, bringing down Belgium's SABENA with it. Several other airlines are in the red and are forced to compete head on with cut-rate carriers. For the consumer, of course, lower prices are good news; price cuts greatly benefit intra-European tourism. In fact, the number of airline passengers has continued to increase after $9 / 11$, although at a more modest rate than before.

Indirectly, tourism is affected by many EU measures. These are compiled in periodic reports, the latest of which is Commission of the European Communities Report (COM) 171.5 This report commented, for instance, on structural funds, which aid regions with lagging economies. Because of tourism's tendency to create jobs, monies from structural funds often go to tourism. COM 171 reported: "Between 1994 and 1999 approximarely 4,200 million Euros were allocated to tourism by the European Regional Development Fund." Thus, whereas Nedre Dalälven was once an industrial stronghold north of Stockholm, now, with funds from the LEADER initiative (about $\$ 6$ million a year), ten counties with matching funds are cooperating with local businesses to promote the area as a tourist destination. Community funds finance an acronym alphabet soup of umbrella programs that sponsor projects in the fields of information technology, agriculture, and transportation, among others.

\section{Diversity in the Union}

In spite of the 1991 Maastricht Treaty that created the EU in its current form and despite having a common currency, the economic climate and business conditions vary considerably among the member states. A diversity of interests, demographics, and economic drivers complicates the prospects for an EU-wide policy on tourism. Consider the following facts: ${ }^{6}$

- The range of tourism's share of the economy measured in GDP and employment varies from 3 to 8 percent.

\footnotetext{
${ }^{5} \mathrm{COM} 171$, op. cit.

${ }^{6}$ Eurostat 1997, 1999, in A Community of Fifteen: Key Figures 2000 edition.
} 
- VAT standard rates vary between 15 percent (Luxembourg) and 25 percent (Sweden and Denmark), with reduced rates for certain sectors that are as low as 2.1 percent (France). Hotel VAT is highest in the U.K. (17.5 percent), and lowest in Luxembourg ( 3 percent) and Portugal ( 5 percent).

- Corporate taxes range from 10 percent in Ireland to 39 percent in Belgium.

- Unemployment in 1998 was 4 percent in the Netherlands, 18.8 percent in Spain, and 9.4 percent in Germany.

- Average GDP per head is 19,040 Euros, ranging from 14,277 Euros in Greece to 35,980 Euros in Luxembourg

The above statistics underline the varying conditions that obtain within the EU, where the stagnant economies of Germany, Italy, and France are paired with a strong U.K. Taxation is among the remaining tools that the European countries have been able to use to stimulate local economies, since monetary policy was handed over to the European Central Bank (ECB) in Frankfurt.

The tourism industry is also diverse and fragmented. Small or medium-size companies comprise 95 percent of the few pan-European chains outside the hotel industry. Diversity is cited by the European Commission as one possible reason that the tourist trade does not get the attention that it deserves. In the absence of a policy, as we have mentioned, any initiative geared at tourism exclusively must have the unanimous backing of the Council of the European Union.? This built-in hurdle will impede substantial improvement in the tourist trade beyond the indirect effects of initiatives such as the Tourism and Employment process (discussed further below).

COM 665 said it best: "Because of its diversity and fragmented nature, the tourism sector has no clear identity. This may, in part, explain why tourism has featured little at the political level, compared with its economic and social importance." 8

${ }^{7}$ Jeffreys, loc. cit.

${ }^{8}$ Commission of the European Communities Report, COM 665. Final, 2001.

\section{A Common Policy-Not!}

In spite of the occasional indirect benefits to tourism that the EU now brings, we are disappointed at how, in their recent work, various councils, working parties, authorities, and other groups authorized by the EU have failed to grasp the fundamental wisdom of developing and implementing a common, EU-wide tourism policy. This failure is particularly glaring when seen against the backdrop of the EU's expenditure of so much organizational effort and money in pursuit of tactical solutions to problems of dubious advantage to the common interests of EU members. Recent EU White Papers, several of which we cite in this commentary, have made clear how overloaded the entire tourism initiative is with reports, working papers, commission findings, and the like, but how elusive has proven the search for an integrated community-wide policy.

It is also clear, however, that the EU has engaged in a significant body of thought and work in identifying the needs of tourism, and in making the necessary arrangements to organize itself into various groups and working parties to address discrete parts of the tourism industry.

Indeed, the EU has been among the first major governmental structures to recognize that virtually the entire supply arm of tourism comes from small- to medium-size enterprises (SMEs), and that in Europe, “...nearly 95 percent of the European tourist businesses [are] microenterprises." The effects of this recognition cannot be overestimated. Because such enterprises are small, scattered, and individually tiny, in effect, many governments, including that of the United States, have had great difficulty in counting, classifying, and enumerating them-making it all the more difficult to create a continent-wide policy. (It is worth noting that one artifact of this difficulty can be seen in the failure of the U.S. Department of Labor to generate a meaningful Standard Industrial Classification [SIC] scheme for employment in the services sector, which is dominated by tourism enterprises.)

\footnotetext{
${ }^{9} \operatorname{COM} 171$, p. 4.
} 
In the EU bureaucracy, tourism now fits under the Tourism Unit of Directorate General Enterprise, somewhat of a demotion. "The Treaty of Maastricht included, for the first time, 'measures in the sphere of tourism' in the list of Community activities foreseen in support of the Community's overall objectives. However, the Treaty gives no particular guidance for a community tourism policy and there is no specific legal base for Community measures on tourism. This means that any act of the Council of Ministers in the field of tourism needs unanimity among all Member States."10 The European Commission launched a proposal, known as "Philoxenia," to assist tourism, but that idea was scrapped because it did not enjoy the required unanimous support of the Council of the European Union.

Although the Philoxenia initiative-an attempt to launch an integrated policy program to assist European tourism - failed because of the unanimity requirement, it was not until April 2000 that the commission realized and accepted that it would not win unanimous assent, subsequently withdrawing it from further consideration. This, more than any other fact, serves to demonstrate the unwieldy and lumbering nature of the commission, in a world that is increasingly marked by a need for nimble organizational forms.

So, no common policy specifically directly at tourism exists in the European Union. Instead, a process called Tourism and Employment was introduced on the grounds that tourism protects as well as creates jobs-especially among SMEs - and that it is a way for young people to enter the job market. DG Enterprises, in its coordinating role, has published a communication, "Working Together for the Future of European Tourism." This item is based on reports on five key issues (information, training, quality, sustainable development, and new technologies) developed by five work groups. The communication recommends ten measures, of which the first is

\footnotetext{
10 Treaty of Maastricht, Article 3(1)u. See: http:// europa.eu.int/comm/enterprise/services/tourism/ tourismeu.htm\#factsandfigures
}

to integrate "the concerns of all tourism stakeholders in Community policies," which is precisely what the EU has failed to do thus far. ${ }^{11}$

\section{Summary and Suggested Next Steps}

In summary, as the French saying goes: plus f̧a change, plus c'est la même chose, more or less. The dropping of barriers for the movement of goods, services, and people; the advent of the Euro; the offer of development grants; and cross-border business growth-all of these factors and more have helped the development of tourism. Despite the gains from these steps, though, the Achilles heel of European tourism continues to be its declining share of non-EU world tourism arrivals and receipts, which have fallen precipitously over the period of 1990 through 2000, from 60 percent in 1990 to 51 percent in $2000 .{ }^{12}$ The Americas and East Asia benefited most from this market shift, of which little note was made in European circles, due principally to an increase in travel demand within the EU (i.e., travel from one member country to another) that helped cover and partially offset the loss of non-EU arrivals. These demand losses have been variously attributed to (among other things) the "been there, done that, bought the tee shirt" phenomenon among North Americans, and to widespread reports in the consumer press warning of rapidly escalating prices for tourism basics, including food, accommodation, entertainment, and ground transport. Recent European Commission findings have reacted to this price concern by stressing the need for greater competitiveness in international tourism markets. This raises the question, of course, of how to make the $\mathrm{EU}$ as a whole more competitive without an EU-wide tourism policy.

To make tourism an even more vital force for economic and social development in Europe and to allow it to compete effectively for its fair share, the subject has to be elevated to the top levels of political discourse. Once this happens, we hope that a comprehensive and cohesive EU-wide stra-

\footnotetext{
${ }^{11}$ See: COM (2001) 665 Final, "Working Together for the Future of European Tourism," November 13, 2001.

${ }^{12}$ Source: World Tourism Organization, loc cit.
} 
tegic plan will be developed to maintain and grow the tourism industry. Such a strategic plan for "Brand Europe" could draw from the experience of various successful branding achievements at the regional level--some by design, others notthat have involved marketing Tuscany, Burgundy, Bavaria, and other locations. Many other regions have strong associations with characteristic products ripe for marketing. Sweden, for example, the birthplace of Volvo, has a program through which you can pick up your car in Gothenburg, tour Europe in it, and then have it shipped to your home anywhere in the world.

A Brand Europe campaign would no doubt encompass a variety of initiatives. We offer three examples of marketing approaches for purposes of illustration. We can imagine, for example, a cooperative marketing campaign aimed at developing tourism to the EU from non-EU countries (which in 2001 consritured only 17 percent of the total, down from 18 percent in 1985) by branding Europe to compete with areas such as the Caribbean, North America, or Southeast and East Asia. A second area of opportunity, reflecting concerns expressed by a number of countries, could involve helping each country develop a distinctive positioning in the marketplace to minimize cannibalization and give tourists specific reasons to visit individual countries. A third example might be aiding the development of multicountry tourism products that take advantage of EU member countries' diverse resources to reinforce the region's competitive advantage. These cross-border initiatives might help unlock the synergies in what is arguably still the most popular tourist region in the world.

The rest of the world is getting smarter about securing the tourism future. Europe needs to take the necessary steps to do the same. With increasing competition for the world's travelers, Europe will only continue losing market share if it does not get its act together.
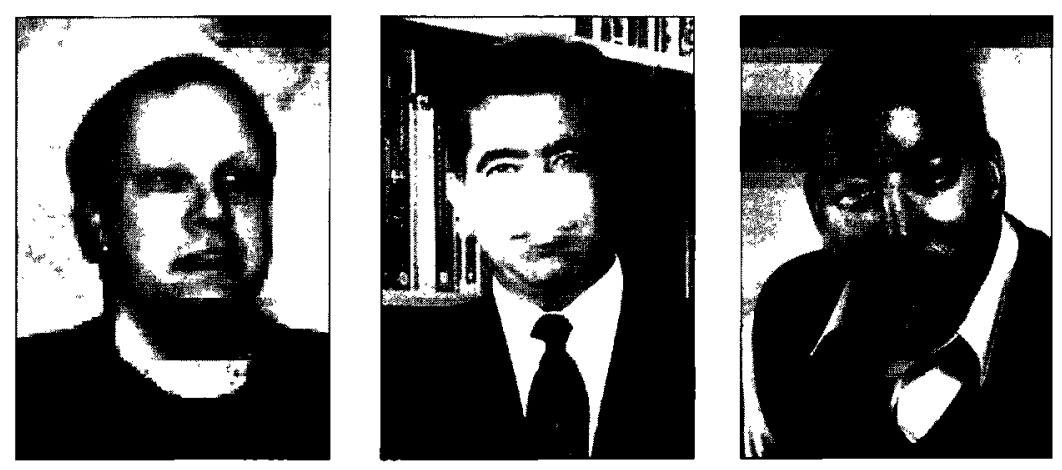

Peter Åkerhielm (photo on far left) is an executive with Present Resor in Bromma, Sweden (peter@ presentresor.info). Chekitan S. Dev, Ph.D. (middle photo), is a marketing professor at Cornell University's School of Hotel Administration (csd5@cornell.edu), where Malcolm A. Noden (photo on immediate left) is a visiting senior lecturer in tourism (man9@cornell.edu) 